\title{
Strengthening social and behavior change monitoring and evaluation for family planning in Francophone West Africa
}

\author{
Leanne Dougherty \\ Population Council \\ Martha Silva \\ Kathryn Spielman \\ Population Council
}

Follow this and additional works at: https://knowledgecommons.popcouncil.org/departments_sbsr-rh

Part of the Health Communication Commons, and the Public Health Commons

How does access to this work benefit you? Let us know!

\section{Recommended Citation}

Dougherty, Leanne, Martha Silva, and Kathryn Spielman. 2020. "Strengthening social and behavior change monitoring and evaluation for family planning in Francophone West Africa," Breakthrough RESEARCH Final Report. Washington, DC: Population Council. 


\section{TECHNICAL REPORT}

\section{Strengthening Social and Behavior Change Monitoring and Evaluation for Family Planning in Francophone West Africa}

APRIL 2020

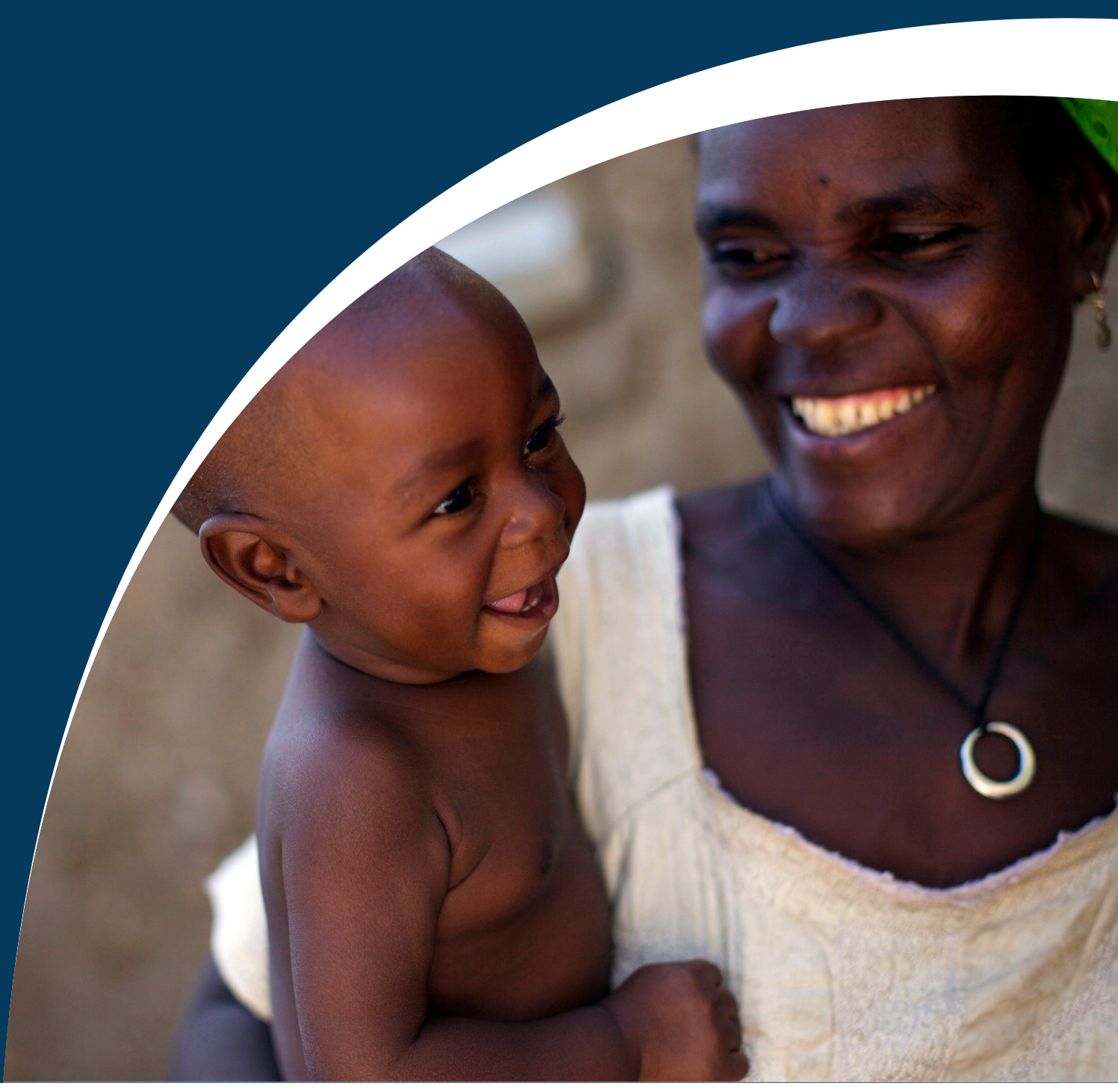

USAID 


\section{Acknowledgments}

We acknowledge the government, donors and technical assistance partners across Burkina Faso, Côte d'Ivoire, Niger and Togo for their contributions, cooperation and partnership during this indicator mapping activity. We appreciate the support of our regional consultants Chaibou Dadi (Niger), Komlan Edan (Togo and Côte d'Ivoire) and Bonaventure Yameogo (Burkina Faso) for their support in engaging with partners and collecting data. We acknowledge Laura Reichenbach and Paul C. Hewett of the Population Council for their technical guidance and review; Alison Collier (consultant) and Sherry Hutchinson of Population Council, who provided editorial and design support; and Hope Hempstone, Lindsay Swisher, and Joan Kraft with the United States Agency for International Development (USAID), who provided valuable feedback during the development of this report.

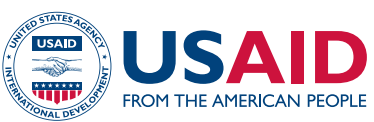

Breakthrough RESEARCH is made possible by the generous support of the American people through the United States Agency for International Development (USAID) under the terms of cooperative agreement no. AID-OAA-A-17-00018. The contents of this document are the sole responsibility of the Breakthrough RESEARCH and Population Council and do not necessarily reflect the views of USAID or the United States Government.

\section{Tulane University}

As stewards of the first school of public health in the United States, the Tulane University School of Public Health and Tropical Medicine cultivates independent thinkers, innovative leaders, fierce advocates, and accomplished scholars.

From the neighborhoods of New Orleans to communities worldwide, we conduct research and collaborate with our partners to ensure that all of humanity has an equitable opportunity to be healthy and pursue optimal well-being.

We train the problem solvers. Find us on the Front Lines.
(C2020 The Population Council. All rights reserved.

Cover photo by (CUNICEF/Benedicte Kurzen. Published under Creative Commons (Attribution, Non-commercial, No Derivative Works) Licence.

\section{Suggested Citation}

Dougherty, Leanne, Martha Silva, and Kathryn Spielman. 2020. "Strengthening social and behavior change monitoring and evaluation for family planning in Francophone West Africa," Breakthrough RESEARCH Final Report. Washington DC: Population Council.

\section{Contact}

4301 Connecticut Avenue NW, Suite 280 | Washington, DC 20008 +12022379400 | BreakthroughResearch@popcouncil.org breakthroughactionandresearch.org

\section{POPULATION COUNCIL}

Ideas. Evidence. Impact.

The Population Council confronts critical health and development issuesfrom stopping the spread of HIV to improving reproductive health and ensuring that young people lead full and productive lives. Through biomedical, social science and public health research in about 50 countries, the Council works with our partners to deliver solutions that lead to more effective policies, programs, and technologies to improve lives worldwide. Established in 1952 and headquartered in New York, the Council is a nongovernmental, nonprofit organization with an international board of trustees.

\section{Breakthrough RESEARCH FOR SOCIAL \& BEHAVIOR CHANGE}

Breakthrough RESEARCH catalyzes social and behavior change (SBC) by conducting state-of-the-art research and evaluation and promoting evidence-based solutions to improve health and development programs around the world. Breakthrough RESEARCH is a consortium led by the Population Council in partnership with Avenir Health, ideas42, Institute for Reproductive Health at Georgetown University, Population Reference Bureau, and Tulane University. 
Strengthening Social and Behavior Change Monitoring and Evaluation for

Family Planning in Francophone West Africa

Leanne Dougherty ${ }^{1} \quad$ Martha Silva $^{2} \quad$ Kathryn Spielman ${ }^{1}$

${ }^{1}$ Population Council

${ }^{2}$ Tulane University 


\section{List of Acronyms}

CBD

DHS

FP

HTSP

IPC

$\mathrm{mCPR}$

PMA

SBC

$\mathrm{RH}$

USAID

WABA
Community-based distribution

Demographic and Health Survey

Family planning

Healthy timing and spacing of pregnancy

Interpersonal communication

Modern contraceptive prevalence rate

Performance Monitoring and Accountability

Social and behavior change

Reproductive health

US Agency for International Development

West Africa Breakthrough ACTION 


\section{Table of Contents}

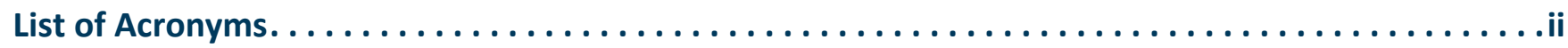

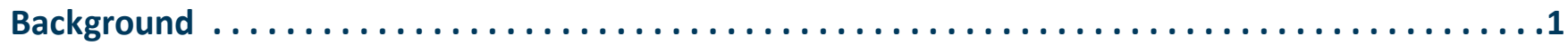

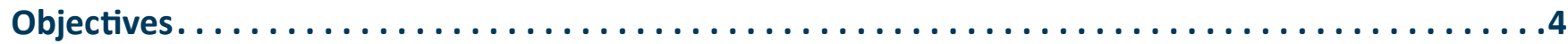

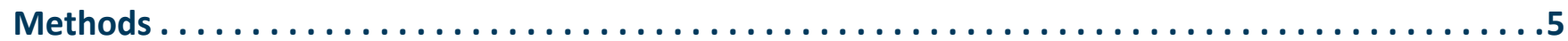

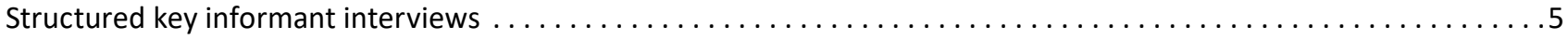

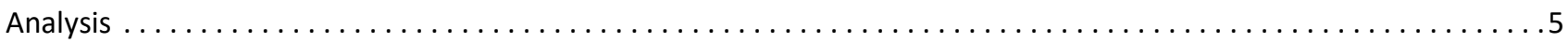

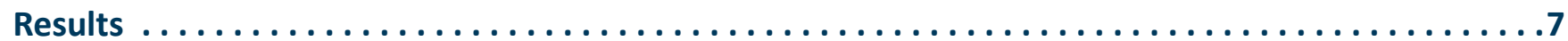

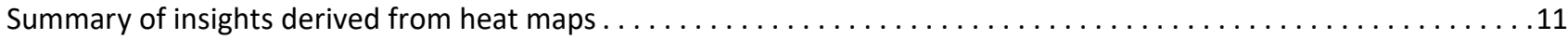

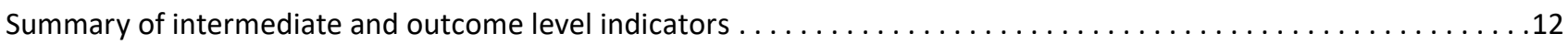

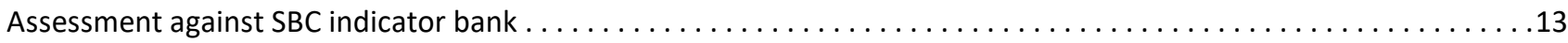

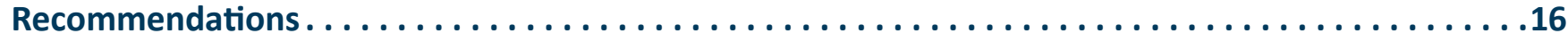

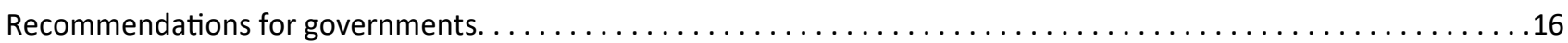

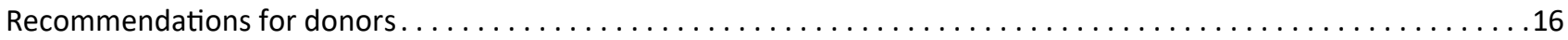

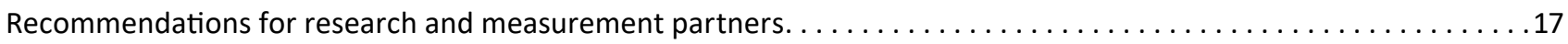

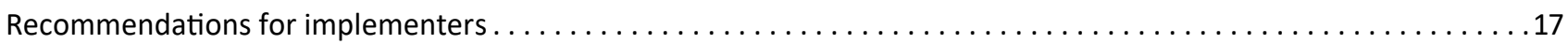

Recommendations for the SBC indicator bank for family planning and service delivery $\ldots \ldots \ldots \ldots \ldots$

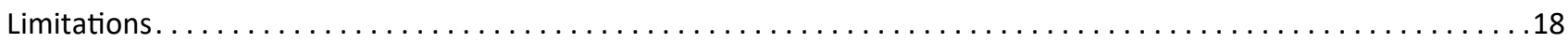

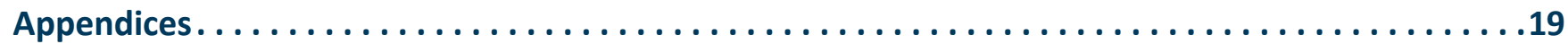

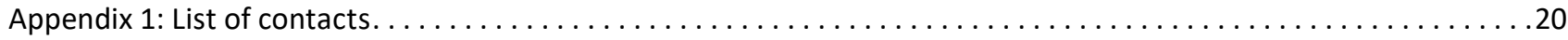

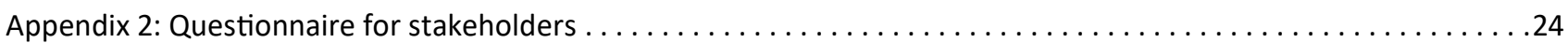

Appendix 3: Indicator matrix of FP investments across the four WABA/Amplify-FP countries . . . . . . . . . . 25

Appendix 4: Summary presentation of FP stakeholder investments across the four WABA/Amplify-FP countries .....25

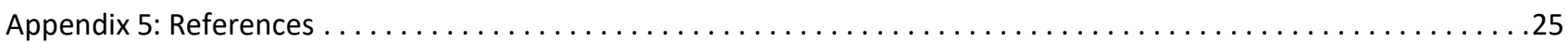




\section{Background}

High maternal morbidity and mortality rates continue to burden francophone West Africa, a sub-region characterized by having the highest fertility rates in the world and a low contraceptive prevalence. Family planning (FP) reduces the number of maternal deaths because it reduces the chance of pregnancy and associated complications, such as the risk of having an unsafe abortion; delays first pregnancy among young women who have premature pelvic development; and reduces the risks from high parity and closely spaced pregnancies. ${ }^{1}$ In 2011, nine governments of francophone West African countries, ${ }^{\mathrm{a}}$ along with technical and financial partners, formed the Ouagadougou Partnership to accelerate progress in the use of FP services in the region. Since its inception, country governments, donors, and technical partners have worked to strengthen FP and reproductive health $(\mathrm{RH})$ programs, predominantly through investments in procurement and supply of commodities and improved service delivery, with less investment in social and behavior change $(\mathrm{SBC})^{\mathrm{b}}$ interventions. ${ }^{\mathrm{c}}$ Breakthrough ACTION-a USAID flagship investment aiming to improve global coordination and implementation of SBC programs-interviewed FP stakeholders to better understand obstacles to SBC inclusion in investments and determined that there are two main barriers: (1) a lack of awareness that SBC is needed to improve outcomes, and (2) a belief that SBC does not generate the same return on investments as service delivery and procurement investments options. ${ }^{2}$

This limited awareness of the role of SBC in improving FP outcomes reflects a lack of understanding of how access and demand factors interact. In 2017, Weinberger et al. analyzed the maximum contraceptive prevalence "demand curve" to show the relationship between the modern contraceptive prevalence rate (mCPR) and mean ideal number of children to assess the balance between access and demand interventions (Figure 1). ${ }^{3}$

${ }^{b}$ Activities used to raise awareness, reduce misinformation, and address the barriers that prevent individuals, families, and communities from practicing lifesaving behaviors to improve health outcomes.

chttps://map.partenariatouaga.org/

ảenin, Burkina Faso, Côte d'Ivoire, Guinea, Mali, Mauritania, Niger,

FIGURE 1 THE MAXIMUM CONTRACEPTIVE PREVALENCE DEMAND CURVE: RELATIONSHIP BETWEEN MCPR (MARRIED/IN-UNION) AND MEAN IDEAL NUMBER OF CHILDREN ${ }^{3}$

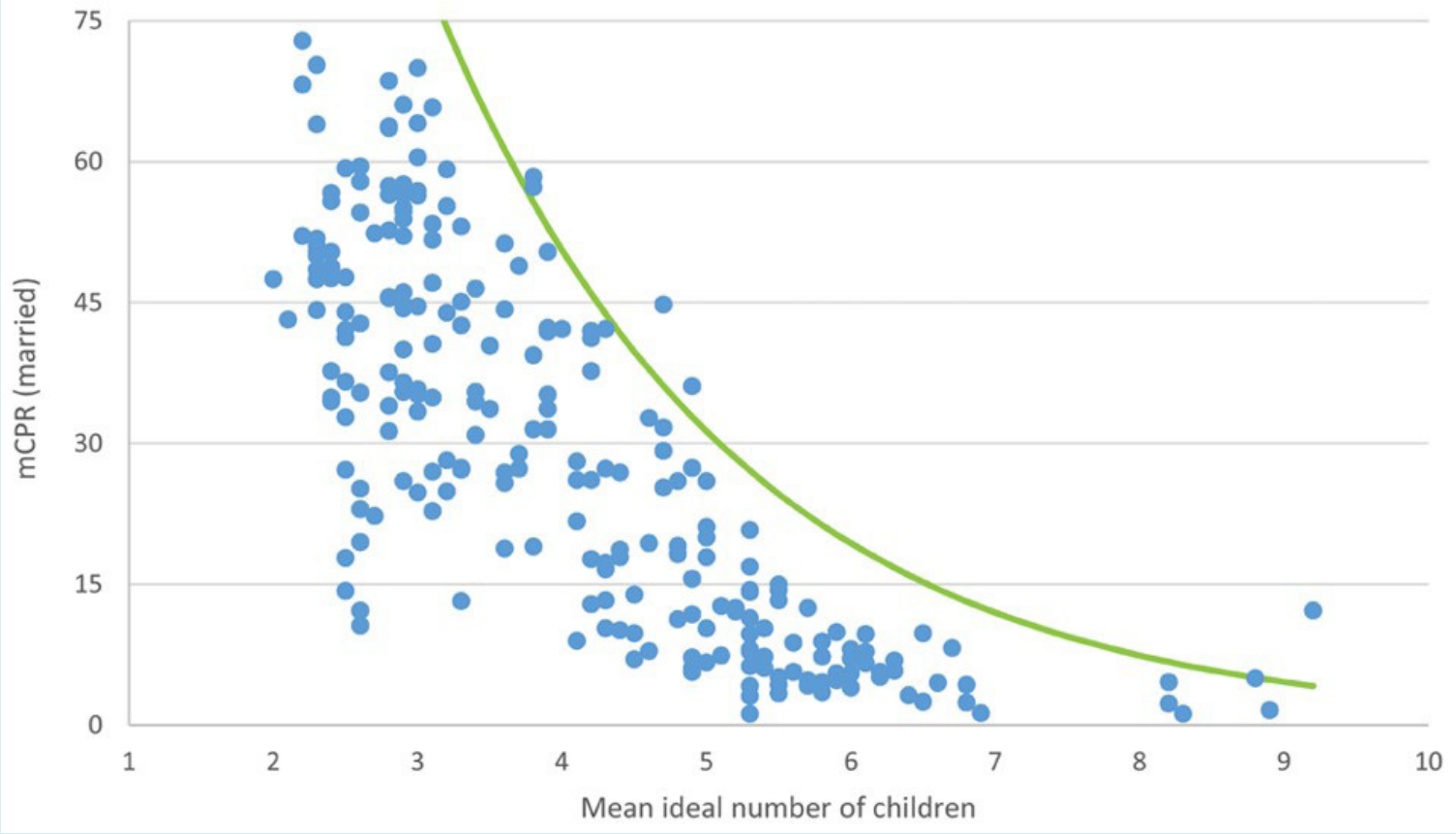


The curve represents the maximum mCPR that is likely given existing fertility intentions and related norms. In countries where there is a high mean ideal number of children, mCPR may remain low without investment in SBC to create demand. ${ }^{3}$ While there is still a need to build the strength of the SBC evidence base through rigorous study designs, a growing body of evidence suggests that SBC interventions increase use of modern contraceptives and, ultimately, generate a positive return on investments. ${ }^{4}$ Evidence suggests that SBC interventions can directly increase contraceptive uptake as well as increase contraceptive use through pathways that address intermediate indicators such as attitudes and communication around family planning (Figure 2). However, some SBC interventions are more effective than others, and the effectiveness of SBC interventions varies depending on the existing $\mathrm{mCPR}$ and intermediate knowledge, attitudes, beliefs, and risk perceptions. ${ }^{4}$

Despite the promise of SBC approaches, when SBC programs are implemented, SBC measurement tools and indicators measuring the domains described in Figure 2 are not systematically applied to monitor and evaluate FP/RH program performance. Global FP partnerships, such as FP2020 and the Ouagadougou Partnership, have regular measurement and reporting systems in place to ensure the latest data are available to support decisions and improve results of FP programs. However, their core indicators focus primarily on contraceptive uptake and service delivery outcomes such as availability of contraceptive methods at facilities.

Availability of SBC-related data, including standardized indicators, would provide several advantages to countries, programs, and global partnerships. First, SBC data are needed for program design, and to continuously monitor program quality and efficiency. Without this information, it is challenging to identify problems and make corrections. Second, SBC data can be used to show that programs have their intended short term and long term effects, which can be used to advocate for further investment. This is particularly true in the Ouagadougou Partnership countries, where many countries still have a high mean ideal number of children and low contraceptive prevalence rates. In addition, standardized SBC indicators at the country level can facilitate collection and aggregation of information at the national level, while regional standardization provides countries with the opportunity to benchmark their progress against other countries. Finally, routine monitoring systems

\section{FIGURE 2 IDEATIONAL MODEL ADAPTED FROM (KINCAID 2000)5}

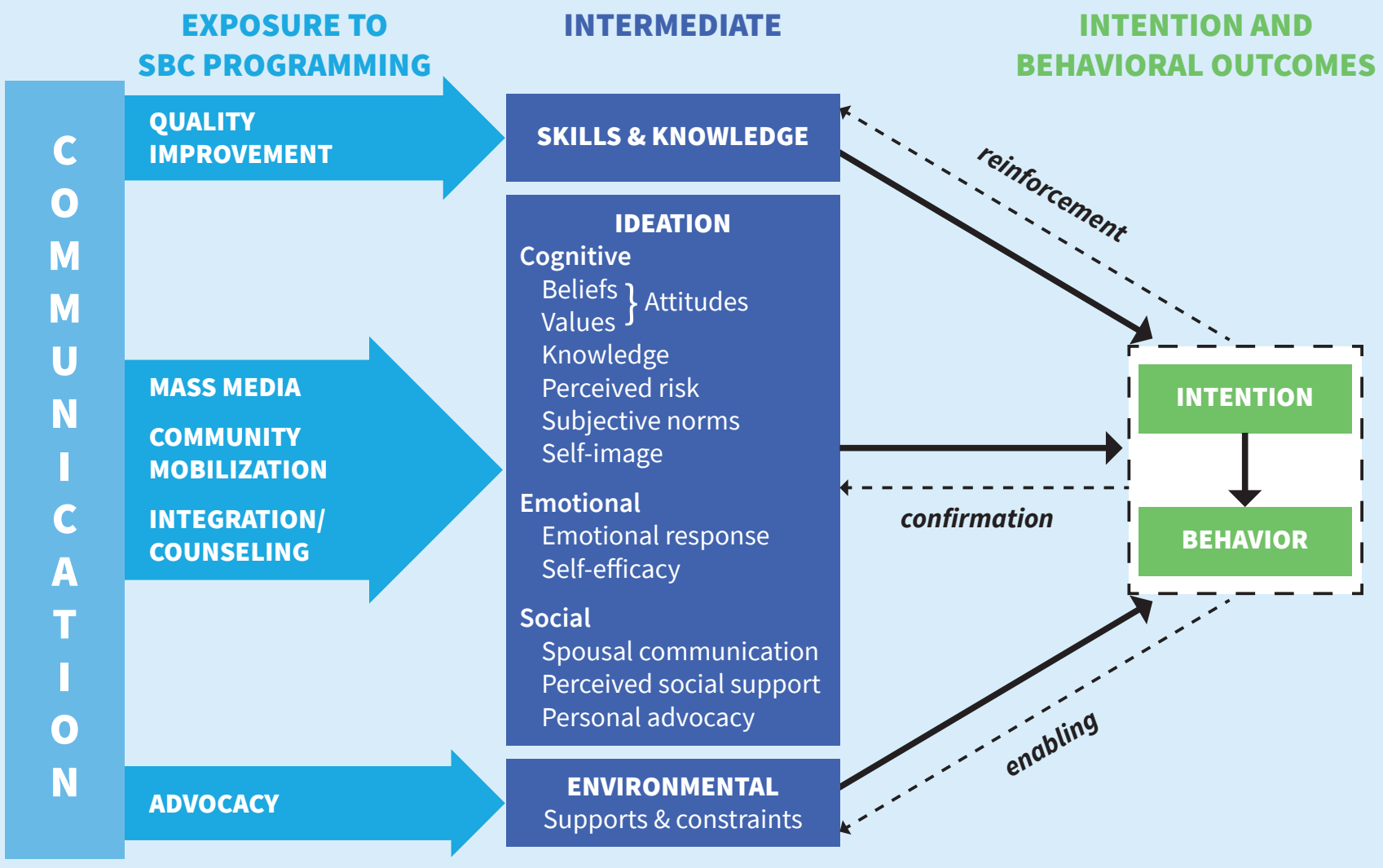




\section{USAID'S SBC INVESTMENTS IN FRANCOPHONE WEST AFRICA}

West Africa Breakthrough ACTION (WABA) is a regional U.S. Agency for International Development (USAID)funded initiative aiming to increase coordination and effectiveness of SBC interventions in four countries: Burkina Faso, Côte d'Ivoire, Niger, and Togo. WABA works in partnership with Amplify-FP, another USAIDfunded project, to strengthen service delivery in these four countries. These investments provide an entry point to explore the SBC programmatic landscape within the region and to identify and document the indicators used in the region, as well as the extent to which important SBC indicators are considered for programmatic attention. Breakthrough RESEARCH, USAID's flagship SBC research project, leveraged this entry point to conduct a mapping of FP investments, technical approaches, and indicators in the four WABA/ Amplify-FP countries to better understand the FP landscape in the region and, ultimately, contribute to improving SBC measures.

using standardized SBC data could be used to design and evaluate programs without the need for one off data collection activities, which could generate cost-savings.

Breakthrough RESEARCH conducted the indicator mapping activity in the four WABA/Amplify-FP countries: Burkina Faso, Côte d'Ivoire, Niger, and Togo (Figure 3). According to the most recent 2018 Performance Monitoring and Accountability (PMA) and 2013-14 Togo Demographic and Health (DHS)d surveys, the Francophone West Africa region has some of the highest fertility rates in the world and low demand for family planning. Niger, at 7.6 average births per woman, is the highest in the world. The MCPR among all women (married and unmarried) is roughly 25 percent (27\% in Burkina Faso, 25\% in Côte d'Ivoire, 22\% in Niger, and 20\% in Togo). The mCPR is closer to 33 percent for married women in all four countries. Unmet need remains quite low in Niger (10\%), and is somewhat higher in Burkina Faso (19\%), Côte d'Ivoire (22\%), and Togo (35\%). However, awareness of modern methods is moderately high-over half of women (between $51 \%$ and $69 \%$ ) are aware of six or more modern methods.

\section{FIGURE 3 MAP OF WEST AFRICA BREAKTHROUGH ACTION FOCAL COUNTRIES}

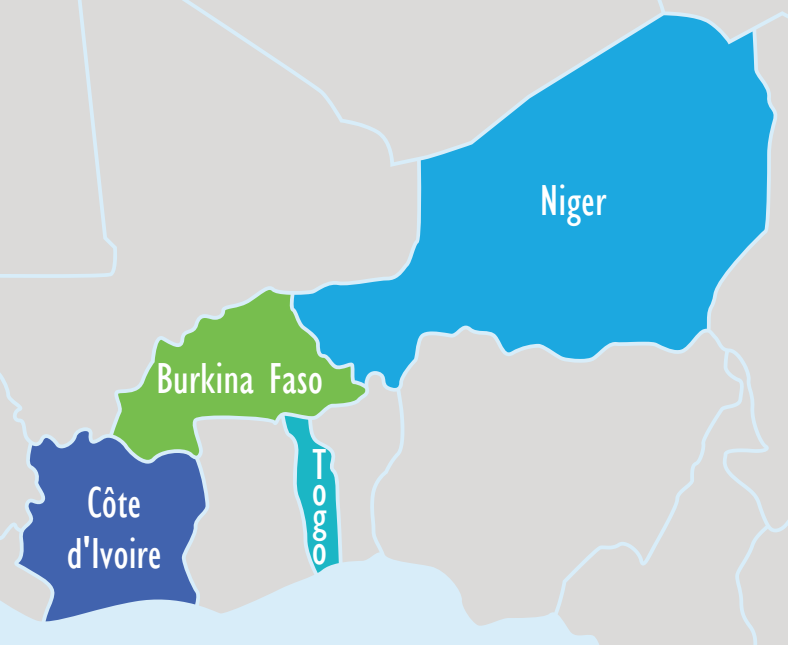

dPMA2020 did not conduct surveys in Togo and so the most recent data are from the 2013-2014 DHS survey

eWomen with unmet need are those who are fecund and sexually active but are not using any method of contraception, and report not wanting any more children or wanting to delay the next child. The concept of unmet need points to the gap between women's reproductive intentions and their contraceptive behavior. Unmet need could be low because women are using contraception. With low $\mathrm{mCPR}$, we interpret low unmet need to suggest there is low demand for FP. 


\section{Objectives}

This report summarizes findings from a mapping of FP investments, technical approaches, and indicators; identifies indicator gaps; and makes recommendations to governments, donors, researchers, and implementers to improve measurement of SBC activities within the broader FP programmatic landscape.

Specifically, we address the following questions:

- What was the landscape of USAID and other donor investments in FP in the five preceding years?

- To what extent are FP indicators collected on 1) programmatic reach, 2) determinants of behavior (factors including knowledge, attitudes, perceived risk, self-efficacy, social norms, spousal communication), 3) service delivery including supply chain, 4) FP-related behaviors (e.g., postpartum FP acceptance and uptake), 5) regional/national/policy, and 6) cost in the four WABA countries?

- What gaps exist and what additional SBC indicators can WABA, Amplify-FP and other relevant projects in the region incorporate into their monitoring and evaluation systems to increase the utility of routine data? 


\section{Methods}

\section{Structured key informant interviews}

Structured key informant interviews with FP stakeholders (primarily project/country directors and monitoring and evaluation officers) in each country were conducted November through December 2019. The purpose of the interviews was to obtain information on FP investments and relevant documents on FP indicators. An initial list of key stakeholder names and contact details were based on discussions with USAID and Breakthrough ACTION. FP stakeholders came from government agencies, financial partners (i.e., USAID, Bill \& Melinda Gates Foundation, and World Bank), for profit and not for profit international and local non-governmental organizations, civil society organizations, the media, and local associations operating over the past five years.

Consultants reviewed the stakeholder lists generated with the general secretariat of the Ministry of Public Health, departments of statistics, and FP to ensure government support and to identify additional stakeholders. The consultants made three attempts to organize an appointment with stakeholders. If they were unsuccessful, information was listed as missing for this respondent, as indicated in Appendix 1. Stakeholders were asked if they knew of any other stakeholders working on family planning and reproductive health that should be contacted, enabling a snowball sampling approach.

During the stakeholder interviews, the consultants administered the structured interview questions (Appendix 2). The consultants requested documentation pertaining to the activity objectives, program descriptions, monitoring-evaluation and learning plans, indicator reference sheets, and other documents. Information on existing data sources such as PMA, DHS, and DHISII indicators was collected as well.

\section{Analysis}

\section{Matrix of FP indicators collected}

Consultants reviewed and synthesized documents into a descriptive report and compiled a list of all indicators into a matrix for each country. The country indicator matrices were aggregated and summarized into one master indicator matrix excel file (Appendix 3). For each indicator, the matrix provides the partner/donor collecting data on the indicator, frequency of data collection, geographic level, definition of the indicator, and year data collection started. As reflected in Table 1, we classified by whether they were SBC-related; the type of indicator by output, programmatic reach, intermediate, and outcomes; and

\section{TABLE 1 INDICATOR DEFINITIONS}

SBC-related indicators: measure SBC processes and techniques to motivate and increase uptake and/or maintenance of health service-related behaviors among intended audiences

\section{Type of indicator:}

- Output-occurs as a result (direct product) of a program's activities

- Programmatic reach-\# or \% of beneficiaries exposed to an intervention

- Intermediate-ideational factors that are considered as contributing to behavioral and health outcomes

- Outcome-desired behavioral or health effect on target audience; may also include unintended behavioral or health effects

\section{Socio-ecological level:}

- Individual-reported at the beneficiary level, including intermediate behavior and health outcomes

- Community-capturing activities at the community level such as community mobilization, community-based distribution (CBD) of contraception, and engagement with community leaders

- Facility-reporting on service delivery providers (SDP), pharmacy, or other FP distribution points not including service delivery in mobile units or CBD

- Project-only relevant to the management of a project

- National-reporting national-level plans in place, policies, national TV and other channels, and government expenditures

- Regional-cover more than one country (not within country) 
the socio-ecological level of the indicator. ${ }^{f}$ The type of indicator is captured to reflect steps in the pathway to achieving outcomes. In a project's theory of change, outputs antecede intermediate outcomes and intermediate outcomes antecede behavioral and health outcomes. ${ }^{6}$ The socio-ecological levels reflect that most public health challenges are too complex to be adequately understood and addressed from single-level analyses. ${ }^{7}$ As a result, the socio-ecological model provides a more comprehensive approach and integrates multiple levels of influence to impact health behavior and, ultimately, health outcomes. Those levels of influence include individual factors, community, facility, and national/regional.

Table 2 illustrates the master indicator matrix. Counts of indicators by type and socio-ecological level were summarized in heat maps to visually explore prevalence of specific types of indicators as well as gaps.

\section{Breakthrough ACTION SBC indicator bank}

In addition to the indicators collected through interviews with key stakeholders, we leveraged the SBC indicator bank for FP and service delivery, developed by Breakthrough ACTION to identify illustrative quality indicators for global programs using SBC approaches to address FP challenges. The Breakthrough ACTION indicator bank provides a sample of indicators for use in SBC programs. The indicator bank builds on well-known indicator sources such as the MEASURE Evaluation's FP/RH Indicator Database as well as from PMA 2020's recommended FP indicators. While the indicator bank provides suggested indicators, it recognizes that countries and stakeholders may need to adjust based on the context.

We compared the master indicator matrix to the Breakthrough ACTION SBC indicator bank. We then identified the SBC indicator bank indicators included in the master indicator matrix and identified the type and socio-ecological level of these indicators. Results were presented again in heat maps to visually explore prevalence of specific types of indicators as well as gaps.

fhttps://breakthroughactionandresearch.org/resources/social-and-be-

havior-change-indicator-bank-for-family-planning-and-service-delivery/

TABLE 2 ILLUSTRATIVE INDICATORS BY TYPE

\begin{tabular}{|c|c|c|c|c|}
\hline & OUTPUT & REACH & INTERMEDIATE & OUTCOME \\
\hline Individual & $\begin{array}{l}\text { Number of male condoms } \\
\text { distributed }\end{array}$ & $\begin{array}{l}\text { Percent of audience who } \\
\text { recall hearing or seeing a } \\
\text { specific product, practice, } \\
\text { or service }\end{array}$ & $\begin{array}{l}\text { Percentage of intended } \\
\text { audience who believe that } \\
\text { most people in their com- } \\
\text { munity approve of people } \\
\text { like them using FP }\end{array}$ & $\begin{array}{l}\text { Percentage of women of repro- } \\
\text { ductive age in union who are } \\
\text { using, or whose male partner is } \\
\text { using, a modern FP method }\end{array}$ \\
\hline Community & $\begin{array}{l}\text { Number of community- } \\
\text { level activities for FP con- } \\
\text { ducted in project sites }\end{array}$ & $\begin{array}{l}\text { Number of community } \\
\text { members participating in } \\
\text { community-level activities } \\
\text { for FP in the last } 6 \text { months }\end{array}$ & $\begin{array}{l}\text { Percentage of community } \\
\text { leaders who believe they } \\
\text { are capable of advocating } \\
\text { for FP use (self-efficacy) }\end{array}$ & $\begin{array}{l}\text { Percentage of villages in a } \\
\text { district with community-based } \\
\text { distribution of contraceptives }\end{array}$ \\
\hline Facility & $\begin{array}{l}\text { Number of providers } \\
\text { trained in high quality } \\
\text { counseling }\end{array}$ & $\begin{array}{l}\text { Percentage of health care } \\
\text { providers in the facility } \\
\text { exposed to a quality im- } \\
\text { provement intervention }\end{array}$ & $\begin{array}{l}\text { Percentage of providers at } \\
\text { maternal and child health } \\
\text { service delivery points } \\
\text { who know the range of } \\
\text { contraceptive options } \\
\text { that do not interfere with } \\
\text { breastfeeding }\end{array}$ & $\begin{array}{l}\text { Percentage of providers who } \\
\text { provided FP counseling accord- } \\
\text { ing to quality standards }\end{array}$ \\
\hline $\begin{array}{l}\text { National/ } \\
\text { policy }\end{array}$ & $\begin{array}{l}\text { Number of workshops } \\
\text { conducted with govern- } \\
\text { ment leaders to speak out } \\
\text { in favor of FP }\end{array}$ & $\begin{array}{l}\text { Number of government } \\
\text { leaders trained to speak } \\
\text { out in favor of FP }\end{array}$ & $\begin{array}{l}\text { Number of government } \\
\text { leaders who feel they are } \\
\text { able to speak out in favor } \\
\text { of FP }\end{array}$ & $\begin{array}{l}\text { National FP communication } \\
\text { strategy approved by the } \\
\text { ministry }\end{array}$ \\
\hline
\end{tabular}




\section{Results}

FP investments in the four countries are driven by government-led strategies and coordination efforts. The governments are supported by a range of partners, who provide financial and technical assistance in developing policy and advocacy approaches, as well as work directly on the ground addressing supply and demand barriers. There are also partners who guide and implement research, monitoring, and evaluation to inform program implementation and impact. The private sector, civil society, and women's and youth's associations also play an active role in service provision and implementation of activities related to demand generation, and in advocacy. A summary of investments by type and country are described in Appendix 4 .

Table 3 provides a summary of the number of stakeholders contacted in each country, the number providing information, and the response rate.

\section{TABLE 3 NUMBER AND RESPONSE RATE OF STAKEHOLDERS BY COUNTRY}

\begin{tabular}{|lccc|} 
& $\begin{array}{c}\text { NUMBER OF } \\
\text { STAKEHOLDERS } \\
\text { IDENTIFIED }\end{array}$ & $\begin{array}{c}\text { NUMBER } \\
\text { PROVIDING } \\
\text { INFORMATION }\end{array}$ & $\begin{array}{c}\text { RESPONSE } \\
\text { RATE } \\
(\%)\end{array}$ \\
\hline Burkina Faso & 32 & 16 & 50 \\
Côte d'Ivoire & 18 & 11 & 61 \\
Niger & 15 & 11 & 73 \\
Togo & 22 & 17 & 77 \\
\hline
\end{tabular}

We collected a total of 1,508 indicators from 55 stakeholder/projects operating in four countries over the last five years. Table 4 provides the number of indicators collected for each stakeholder/project. Only about half of all indicators included indicator definitions and information on the frequency with which data were reported. Among the 45 percent of indicators that reported frequency of data collection, about half of those indicators were reported on a monthly or quarterly basis; differences in frequency of reporting were seen by type of indicator. Output level indicators were most frequently reported quarterly, while intermediate level indicators and outcome indicators were more frequently reported annually. Indicators that were disaggregated were most frequently at the individual level. Where available, disaggregation was commonly reported by marital status, sex, and age.
We prepared heat maps by type of indicator and the socio-ecological level reported. We first looked at all indicators (Table 5) and then indicators specific to SBC programs for all four countries (Table 6). We also collected FP project management related indicators, but they are excluded from the analysis because they were primarily collected for project accountability purposes and were less relevant for the purposes of this documentation. 
TABLE 4 NUMBER OF ALL INDICATORS BY COUNTRY AND STAKEHOLDER/PROJECT $(\mathbf{N}=1,508)$

\begin{tabular}{|c|c|c|c|c|}
\hline & $\begin{array}{l}\text { BURKINA FASO } \\
\quad \mathrm{N}=539\end{array}$ & $\begin{array}{l}\text { CÔTE D'IVOIRE } \\
\qquad \mathrm{N}=406\end{array}$ & $\begin{array}{l}\text { NIGER } \\
\text { N=266 }\end{array}$ & $\begin{array}{l}\text { TOGO } \\
\mathrm{N}=297\end{array}$ \\
\hline \multicolumn{5}{|l|}{ Government } \\
\hline $\begin{array}{l}\text { MoH National FP acceleration plan/ Government (FP national bud- } \\
\text { get action plan [PANB]) }\end{array}$ & 188 & 98 & 67 & 47 \\
\hline $\begin{array}{l}\text { Annuaire Statistique de la Santé is compiled by the Ministry of } \\
\text { Health; data mainly come from health centers }\end{array}$ & 9 & NA & NR & 34 \\
\hline Direction of statistics & NR & NA & 15 & $20^{\ddagger}$ \\
\hline $\begin{array}{l}\text { National program coordination for maternal and child health (DC- } \\
\text { PNSME) }\end{array}$ & NR & 16 & NA & NA \\
\hline \multicolumn{5}{|l|}{ Regional projects (USAID) } \\
\hline Breakthrough ACTION & 61 & 31 & 32 & 44 \\
\hline Amplify-FP & 21 & 4 & 4 & 21 \\
\hline Health Policy Project & 44 & 44 & 44 & 45 \\
\hline \multicolumn{5}{|l|}{ Regional projects (non-USAID) } \\
\hline Track20 & 18 & 20 & NR & 22 \\
\hline PMA2020 & 22 & 3 & 3 & NA \\
\hline SWEDD & 18 & 42 & NR & NA \\
\hline \multicolumn{5}{|l|}{ Civil society and local organizations } \\
\hline IPPF affiliate (i.e., AIBEF, ATBEF, ABBEF) & 10 & 26 & NR & 17 \\
\hline $\begin{array}{l}\text { Social marketing organizations (i.e., PROMACO, AIMAS, Animas } \\
\text { Sutura) }\end{array}$ & NR & 118 & 22 & NR \\
\hline ARSIP (religious civil society) & NA & 4 & NA & NA \\
\hline ABSFM & 17 & NA & NA & NA \\
\hline ADESCO (support for community health development) & NA & NA & NA & 20 \\
\hline CSO Platform + HIV/Health & NA & NA & NA & 2 \\
\hline ROSCI (Network of RH/FP CSOs) & NA & NA & NA & 7 \\
\hline \multicolumn{5}{|l|}{ Other investments } \\
\hline Closing the gap & 70 & NA & NA & NA \\
\hline Engender health & 24 & NR & NR & NR \\
\hline PSI & NA & NR & 31 & NA \\
\hline Pathfinder IMPACT & NA & NA & 25 & NA \\
\hline Development food security activities (DFSAs) (Care, CRS, Save) & NR & NA & 23 & NA \\
\hline Large anonymous donors & 21 & NA & NA & NA \\
\hline $\mathrm{GIZ/Sante} \mathrm{Integree}$ & NA & NA & NR & 9 \\
\hline UNFPA & NR & NR & NR & 6 \\
\hline Other & 16 & NA & NA & 3 \\
\hline
\end{tabular}

${ }^{\dagger}$ Not application (NA); No response (NR); ‡INSED (Institut National de la Statitique et des Etudes Economiques et Demographique) 
TABLE 5 HEAT MAP OF ALL INDICATORS BY COUNTRY, TYPE, AND SOCIO-ECOLOGICAL LEVEL $(\mathrm{N}=1,508)$

\begin{tabular}{lcccccc}
\hline CÔTE D'IVOIRE & OUTPUT & REACH & INTERMEDIATE & OUTCOME & LEGEND \\
\hline Individual & 14 & 26 & 26 & 74 & & 81 \\
Community & 67 & 7 & 0 & 1 & 0 & \\
Facility & 81 & 0 & 0 & 3 & & \\
Regional/national/policy & 44 & 0 & 7 & 26 &
\end{tabular}

Total number of indicators:

Excludes 30 project indicators

\begin{tabular}{lcccc|c|c}
\hline BURKINA FASO & OUTPUT & REACH & INTERMEDIATE & OUTCOME & LEGEND \\
\hline Individual & 11 & 27 & 27 & 145 & & 145 \\
Community & 30 & 1 & 1 & 1 & 0 & \\
Facility & 68 & 0 & 0 & 2 & & \\
Regional/national/policy & 120 & 15 & 8 & 26 &
\end{tabular}

Total number of indicators:

Excludes 57 project indicators

\begin{tabular}{|c|c|c|c|c|c|c|}
\hline TOGO & OUTPUT & REACH & INTERMEDIATE & OUTCOME & LEGEND & \\
\hline Individual & 4 & 9 & 21 & 55 & & \\
\hline Community & 14 & 0 & 0 & 1 & 0 & 93 \\
\hline Facility & 28 & 0 & 0 & 0 & & \\
\hline Regional/national/policy & 93 & 1 & 8 & 30 & & \\
\hline
\end{tabular}

Total number of indicators:

297

Excludes 33 project indicators

\begin{tabular}{lcccc|c|c}
\hline NIGER & OUTPUT & REACH & INTERMEDIATE & OUTCOME & LEGEND \\
\hline Individual & 2 & 10 & 39 & 36 & & 60 \\
Community & 26 & 0 & 1 & 2 & 0 & \\
Facility & 33 & 0 & 0 & 1 & \\
Regional/national/policy & 60 & 3 & 8 & 28 &
\end{tabular}

Total number of indicators:

Excludes 17 project indicators 
TABLE 6 HEAT MAP OF SBC-SPECIFIC INDICATORS BY COUNTRY, TYPE, AND SOCIO-ECOLOGICAL MODEL $(\mathrm{N}=810)$

$\begin{array}{lcccccc}\text { CÔTE D'IVOIRE SBC } & \text { OUTPUT } & \text { REACH } & \text { INTERMEDIATE } & \text { OUTCOME } & \text { LEGEND } \\ \text { Individual } & 0 & 20 & 25 & 60 & & 60 \\ \text { Community } & 56 & 7 & 0 & 1 & 0 & \\ \text { Facility } & 5 & 0 & 0 & 1 & \\ \text { Regional/national/policy } & 20 & 0 & 0 & 0 & \end{array}$

Total number of indicators

199

Excludes 4 project indicators

\begin{tabular}{lcccccc}
\hline BURKINA FASO SBC & OUTPUT & REACH & INTERMEDIATE & OUTCOME & LEGEND \\
\hline Individual & 8 & 26 & 27 & 138 & & 138 \\
Community & 20 & 1 & 1 & 1 & 0 & \\
Facility & 19 & 0 & 0 & 0 & \\
Regional/national/policy & 83 & 15 & 0 & 0 &
\end{tabular}

Total number of indicators

356

Excludes 17 project indicators

\begin{tabular}{lccccc|c}
\hline TOGO SBC & OUTPUT & REACH & INTERMEDIATE & OUTCOME & LEGEND \\
\hline Individual & 1 & 9 & 20 & 49 & & 49 \\
Community & 12 & 0 & 0 & 1 & 0 & \\
Facility & 7 & 0 & 0 & 0 & & \\
Regional/national/policy & 29 & 1 & 1 & 2 &
\end{tabular}

Total number of indicators

135

Excludes 3 project indicators

\begin{tabular}{|c|c|c|c|c|c|c|}
\hline NIGER SBC & OUTPUT & REACH & INTERMEDIATE & OUTCOME & LEGEND & \\
\hline Individual & 0 & 9 & 34 & 31 & & \\
\hline Community & 14 & 0 & 1 & 2 & 0 & 34 \\
\hline Facility & 3 & 0 & 0 & 0 & & \\
\hline Regional/national/policy & 19 & 3 & 1 & 1 & & \\
\hline
\end{tabular}

Total number of indicators

Excludes 2 project indicators 


\section{Summary of insights derived from heat maps}

\section{The predominant number of indicators collected in each country were at the output level.}

Overall, we found the highest concentration of indicators at the output level reflecting the ease and comparative low cost of collecting data related to programmatic activities. Output level indicators provide an opportunity to measure the extent to which the program adhered to the original project design during implementation (fidelity), including the level of activities delivered and participation (dose delivered and received). Output level indicators were captured across socio-ecological levels. However, when we restricted the analysis to SBC indicators, we found fewer output level indicators at the individual level. This may be because individual output level indicators are based on the result of a programmatic activity, which is similar in definition to programmatic reach and focuses on beneficiaries exposed to a programmatic intervention (refer to Table 2 for illustrative indicators on individual output and reach).

\section{There are few measures related to reach or ex- posure of beneficiaries to interventions.}

Despite collecting over 1,500 indicators across four countries, we found relatively few indicators that measured exposure to interventions. Among those identified, almost all were concentrated at the individual level. Burkina Faso registered the greatest number of reach indicators, mostly consisting of more general measures of exposure to FP information, messages, and interventions by type of channel (i.e., mass media, toll-free numbers, community events, interpersonal communication, microprograms, etc.). Côte d'Ivoire and Togo, with fewer indicators, had a variety of indicators that represented both specific measures of exposure to a project-based intervention and general indicators of exposure to any FP message. By contrast, reach indicators compiled for Niger were all project based and specific to certain interventions. Measures of exposure observed tracked whether exposure had occurred only, and not level of exposure, making secondary analyses related to dose response difficult to carry out.

\section{Among the ideational factors measured, most focus on awareness, knowledge, and partner communication.}

Among the intermediate indicators collected, the majority measured awareness and knowledge (i.e., awareness/ knowledge of FP methods, knowledge of side effects, knowledge of the benefits of FP, knowledge on where to get an FP method), and partner communication and support (i.e., women were able to talk to husbands about using modern FP, decision making about FP (with partner or independently), women's perceived support by husbands for FP, men committed to FP promotion/women's rights).

\section{Intermediate indicators measuring ideational factors such as attitudes, self-efficacy, risk perceptions, and social norms were not widely represented.}

Understanding ideational factors such as attitudes, self-efficacy, risk perceptions, and social norms, and measuring their relative contribution to behavioral uptake in each setting, is essential in designing effective SBC programming and monitoring its progress. However, despite their importance, relatively few ideational indicators were captured outside awareness of contraception, and they were all concentrated at the individual level. The lack of intermediate indicators at the community level indicates that there may be a need to focus on capturing more normative measures of behavior change, as awareness of methods without favorable attitudes and enabling social norms is insufficient for behavior change.

\section{Although most programs typically target all reproductive age women, there are some in- dicators that focus on key audiences such as adolescents or women who are post-partum or receiving post-abortion care. However, there are few indicators that address audiences such as older women or high parity women.}

Some projects focus on target populations that are at greater risk of an unintended pregnancy, such as adolescents and women who were recently pregnant, resulting in specific measures to monitor progress in addressing their needs. However, we did not find many indicators that focused on high impact practices, such as limiting family size or avoiding high risk pregnancies over the age of 35 , where more efforts may be needed to address behavioral determinants and increase demand for family planning. 
Nationally representative household surveys lack SBC-relevant measures beyond knowledge, such as program exposure and behavioral determinants, which limits their use for SBC program design and evaluation.

The availability of household surveys through PMA, and DHS provided opportunities to collect information related to behavioral outcomes, such as contraceptive prevalence, unmet need for contraception, postpartum family planning, and method discontinuation. The surveys have not traditionally focused on measures of exposure to programming and/or ideational factors beyond knowledge that determine FP uptake and continued use. The lack of SBC-relevant measures makes these surveys of limited use for program design and evaluation.

\section{Among the indicators relevant to SBC programs,} there were few indicators relevant to SBC programming at the provider level, such as attitudes, beliefs, and communication practices.

While there are many service delivery indicators, there are few indicators at the facility level related to SBC, particularly when focusing on reach, intermediate, and outcome level indicators. This may reflect limited investment or measurement of SBC-related programs targeting provider behavior change.

\section{There were very few indicators that measured costs.}

Despite capturing over 1,500 indicators, we identified few indicators related to cost. The measures focused on cost-effectiveness ratio per couple years of protection and dollar amount mobilized through in-kind contributions to support the scale-up of integrated learning networks and high impact practices.

\section{The limited number of policy indicators, partic- ularly at the outcome level, may reflect mea- surement challenges.}

Achieving success at the policy level is challenging to report quantitatively, as this often reflects a lengthy process of engagement across stakeholders. However, monitoring political will, policy changes, coalition building, and resource allocation is important to ensure that an effective, enabling environment is in place to support demand creation.

\section{Summary of intermediate and outcome level indicators}

Overall, we found a broad range of indicators reported across type and level. We identified the most frequently used intermediate and outcomes indicators. Output and reach indicators were excluded from this summary, as they are defined by activities that vary with each program. Table 7 presents the intermediate and outcome indicators that were most frequently reported across countries. Of the 121 intermediate level indicators collected, four indicators (representing nearly $20 \%$ of all intermediate indicators) were consistently reported across stakeholders and countries. Three measures focused on family planning knowledge, and one indicator focused on spousal support. Among the 340 outcome level indicators, the most frequent indicators (representing nearly $40 \%$ of all outcome indicators) focused on contraceptive use reported in terms of new users, total number of users, and contraceptive prevalence rates. There were also several frequently used measures related to discontinuation and unmet need.

\section{TABLE 7 FREQUENTLY REPORTED INTERME- DIATE AND OUTCOME LEVEL FP INDICATORS AMONG ALL INTERMEDI- ATE AND OUTCOME INDICATORS REPORTED IN THE INDICATOR MATRIX}

\begin{tabular}{|lc|}
\hline INTERMEDIATE LEVEL INDICATORS & $\begin{array}{c}\text { FREQUENCY } \\
\text { N=121 (\%) }\end{array}$ \\
\hline Knowledge about FP methods & $11(9)$ \\
Awareness of 3+ modern contraceptive methods & $7(6)$ \\
Adolescent or youth with sexual and RH knowledge & $4(3)$ \\
Spousal support for FP & $3(3)$ \\
\hline OUTCOME LEVEL INDICATORS & $\begin{array}{l}\text { FREQUENCY } \\
\text { N=340 (\%) }\end{array}$ \\
\hline $\begin{array}{l}\text { Additional modern contraceptive users/new FP } \\
\text { users }\end{array}$ & $31(9)$ \\
Modern contraceptive users/use rate & $27(8)$ \\
(Modern) contraceptive prevalence & $23(7)$ \\
FP uptake after abortion & $13(4)$ \\
Unsafe abortions averted due to modern & $5(2)$ \\
contraception & \\
Modern contraceptive discontinuation/FP & $9(3)$ \\
discontinuation/abandonnent & \\
Unmet need for family planning & $8(2)$ \\
Postpartum FP uptake & $9(3)$ \\
Maternal deaths averted due to modern & $5(2)$ \\
\hline
\end{tabular}




\section{Assessment against SBC indicator bank}

Next, we compare against the SBC indictor bank for FP and service delivery. While a standardized and validated compendium of SBC indicators does not yet exist, we use this indicator bank as a benchmark for understanding to what extent stakeholders in each country make use of indicators that monitor and inform SBC programs.

Table 8 provides an illustration of the extent to which indicators available in the SBC indicator bank are represented by the indicators collected in the indicator matrix. The numerator is the number of unique indicators by type and level from the indicator matrix. The denominator is the total number of indicators by type and level, as reflected in the SBC for service delivery indicator bank. The SBC indicator bank includes 72 indicators. We found that stakeholders across the four countries used, to varying degrees, 48 percent of the indicators included in the indicator bank. Approximately 21 percent of the indicators in the indicator bank were similar to the indicators found in the matrix, and 31 percent did not match.

\section{SBC indicator bank indicators}

Among output level indicators captured in the indicator mapping, we found countries were not measuring some individual and facility level indicators related to

\section{TABLE 8 PERCENTAGE OF INDICATORS FROM SBC INDICATOR BANK REPRESENTED IN INDICATOR MATRIX ( $N=71$ ) (FOR EXAMPLE, 100\% PERCENT OF INDICATORS IN THE SBC INDICATOR BANK WERE REPRESENTED IN THE INDICATOR MATRIX AT THE INDIVIDUAL REACH LEVEL IN COTE D'IVOIRE)}

\begin{tabular}{lcccc}
\hline CÔTE D'IVOIRE & OUTPUT & REACH & INTERMEDIATE & OUTCOME \\
\hline Individual & - & $100 \%$ & $42 \%$ & $64 \%$ \\
Community & $100 \%$ & $100 \%$ & - & - \\
Facility & $53 \%$ & - & $0 \%$ & - \\
Regional/national/policy & $40 \%$ & - & - & $0 \%$ \\
Total number of indicators & & & 38 &
\end{tabular}

\begin{tabular}{lcccc}
\hline BURKINA FASO & OUTPUT & REACH & INTERMEDIATE & OUTCOME \\
\hline Individual & - & $75 \%$ & $29 \%$ & $57 \%$ \\
Community & $100 \%$ & $100 \%$ & - & - \\
Facility & $40 \%$ & - & $0 \%$ & - \\
\hline Regional/national/policy & $60 \%$ & - & - & $0 \%$ \\
\hline
\end{tabular}

Total number of indicators

32

\begin{tabular}{lcccc}
\hline TOGO & OUTPUT & REACH & INTERMEDIATE & OUTCOME \\
\hline Individual & - & $75 \%$ & $25 \%$ & $57 \%$ \\
Community & $100 \%$ & $100 \%$ & - & - \\
Facility & $33 \%$ & - & $0 \%$ & - \\
Regional/national/policy & $80 \%$ & - & - & $0 \%$
\end{tabular}

Total number of indicators

31

\begin{tabular}{lcccc}
\hline NIGER & OUTPUT & REACH & INTERMEDIATE & OUTCOME \\
\hline Individual & - & $50 \%$ & $13 \%$ & $36 \%$ \\
\hline Community & $67 \%$ & $100 \%$ & - & - \\
Facility & $27 \%$ & - & $0 \%$ & - \\
\hline Regional/national/policy & $20 \%$ & - & - & $0 \%$ \\
\hline
\end{tabular}

Total number of indicators 
counseling and quality that were included in the SBC indicator bank. Some examples of SBC indicator bank output indicators not captured in our matrices include: number/percent of women who delivered in a facility and received counseling on FP prior to discharge; percentage of women of reproductive age that were informed of other FP methods besides their preferred method, among those that visited an FP provider in the past 12 months; percent of long-acting or permanent method counseling sessions that were deemed high quality and comprehensive.

We found community level output indicators from the SBC indicator bank were well represented, but there were fewer indicators that focused on the individual, facility, and policy level in the matrix.

\section{SBC indicator bank intermediate indicators}

We also found disconnects in intermediate indicators when comparing indicators monitored and indicators in the SBC indicator bank. For example, among the indicators in the SBC indicator bank, there were indicators related to favorable attitudes toward FP, perceived norms, perceived support, perceived self-efficacy, quality of care, and provider knowledge that were not captured during the indicator mapping. Nonetheless, we did find overlap between intermediate indicators collected and in the indicator bank. For example, knowledge of FP methods, intention to adopt FP, and talking to others (friend, relative, community, provider) about FP. We did not find many community or policy intermediate level indicators.

\section{SBC indicator bank outcome indicators}

Individual outcome indicators from the indicator bank were commonly included, but outcome level indicators from the community and facility level were not well represented. Outcome level indicators collected during the indicator mapping that were also included in the SBC indicator bank included use of FP, FP continuation and discontinuation rates, postpartum FP, and post-abortion FP. We did not find indicators on method switching, government leaders who speak out in favor of FP, and women exposed to counseling who subsequently adopted an FP method.

Table 9 presents a list of indicators in the SBC data bank that are not currently being used by stakeholders. The indicators were identified based on a comparison of indicators collected and compiled in the indicator matrix against indicators recommended in the SBC service delivery indicator bank. Based on this comparison, a number of observations emerged. First, the SBC indicator bank did not include indicators in several categories including: intermediate and outcome level indicators at the community level; reach and outcome indicators at the facility level; and reach and intermediate indicators at the national/policy level. While this suggests that there is less demand for these types of indicators, it may still be useful to consider adopting some of these indicators at a country level to ensure that progress in these areas is systematically tracked.

Another observation from the table is that while there are intermediate facility level indicators and outcome national/policy level indicators in the SBC indicator data bank, the indicator mapping did not identify any of these indicators in use. More effort may be required by countries to consider these types of indicators in their monitoring plans. And, the SBC indicator bank may need to review their indicators in these categories to ensure they are reflecting the practice in the field. We also noted that intermediate indicators at the individual level, while available in the SBC indicator bank, were not well reflected in the indicators collected through the indicator mapping.

Among the areas where there was significant overlap, we determined that the community indicators at the individual and reach level in the SBC indicator data bank were nearly universally used in all four countries. We also noted a strong overlap among outcome indicators at the individual level. This is largely due to the availability of household surveys that capture standardized indicators. 


\section{TABLE 9 LIST OF ADDITIONAL INDICATORS FOR POSSIBLE INCORPORATION INTO SBC MONITORING SYSTEMS}

Number of SBC interventions implemented to support or improve FP services

Output

Number of government leaders who speak out in favor of FP

Outcome

National

Percentage of women of reproductive age that were informed of other FP methods besides their preferred method, among those that visited an FP provider in the past 12 months (or a specified reference period)

Output

Facility

Percentage of intended audience members with favorable attitudes toward FP providers

Intermediate

Individual

Percentage of intended audience who believe that most people in their community approve of people like them using FP

Intermediate Individual

Percentage of intended audience with favorable attitudes toward FP

Intermediate Individual

Percentage of intended audience with favorable attitudes toward modern FP methods

Intermediate Individual

Percentage of individuals of reproductive age who are confident in their ability to use FP

Intermediate

Individual

Percentage of intended audience who approve of FP use

Intermediate

Individual

Percentage of intended audience who believe that their religious leaders would approve of people like them using FP

Intermediate Individual

Percentage of intended audience who believe that their spouse/partner would approve of them using FP to space pregnancies

Intermediate Individual

Percentage of intended audience who discussed FP with their spouse/partner in the last 12

months and think their spouse/partner values their opinion on whether to use FP

Intermediate Individual

Percentage of women of reproductive age who would refer others to their FP provider, among

those who have visited a FP provider in the last 12 months

Intermediate Individual

Percentage of FP service providers reporting the use of FP communication materials in the past three months (or a specified reference period)

Output Facility

Percentage of individuals of the intended audience who talked about FP with their spouse/partner in the last 12 months (or a specified reference period)

Intermediate Individual

Percent of maternal and child health services clients who received counseling about the

lactational amenorrhea method (LAM)

Output Individual

Number/percent of women who delivered in a facility and received counseling on FP prior to discharge

Output

Individual

Method switching

Outcome

Individual

Reasons for discontinuation of contraceptive methods

Outcome

Individual

Percent of audience with a favorable (or unfavorable) attitude toward the product, practice, or service

Intermediate Individual

Percent of providers at maternal and child health service delivery points who know the range of contraceptive options that do not interfere with breastfeeding

Intermediate Facility

10-item process quality measure index

Intermediate Facility

Percent of married women under age 18 exposed to healthy timing and spacing of pregnancy

(HTSP) counseling/education who subsequently adopted an FP method to delay first pregnancy

Reach

Individual

Percent of health and non-health workers trained in HTSP who can state the three HTSP recommendations, by type of trainee

Intermediate Facility

Percent of women with a child under age two exposed to HTSP counseling/education who subsequently adopted an FP method in order to space their next pregnancy

Outcome Individual

Percent of long-acting or permanent method counseling sessions that were deemed high quality and comprehensive

Output Individual




\section{Recommendations}

Findings from this indicator mapping exercise have led to insights to inform SBC investments and SBC monitoring and evaluation. The following recommendations are based on the results of this review.

\section{Recommendations for governments}

- Government routine monitoring systems should track key SBC indicators. Monitoring of key SBC indicators by governments can provide insights into barriers and facilitators of health behaviors. This can lead to improved targeting of SBC and service delivery programming. Community-based health workers may be an untapped or underutilized cadre to collect this information. Often community-based health workers were already collecting and transmitting data to health facilities or districts but were not currently collecting SBC-relevant indicators. A successful example of a partnership between a government and financial and technical partners comes from Ghana. USAID's investment "Communicate for Health" brought together a consortium of partners and developed a roadmap for a robust monitoring and evaluation system. The process resulted in 33 SBC indicators developed, 22 of which are now routinely captured in the DHMIS2 platform. 8

- Adoption of standardized SBC measures, such as those in the FP indicator bank, would allow for more reliable and valid national reporting, as well as cross-country comparability in these key measures. This would lead to a clearer understanding of the behavioral drivers that require attention in each country and allow for cross-country fertilization of programmatic approaches that effectively address barriers to advance access and utilization of family planning service. Countries such as Côte d'Ivoire are currently in the process of revising their national health indicators. It is recommended that partners involved in the implementation of FP projects be included in this process to contribute insights and come to consensus regarding the important indicators to include moving forward. Joint reflection is needed to agree on measures not yet standardized, such as estimating the contraceptive products sold by private pharmacies or the contextually-specific priority SBC measures.
- Governments should continue to invest in data quality assessments and explore innovative methods to improve data quality. There is increasing integration of mobile data collection to obtain more timely, complete, and reliable data. Machine learning approaches are being integrated into data analysis to find data faults and gaps. Governments should consider assigning staff as focal points for technological adaption and promoting the pilot testing and adoption of innovative approaches.

- Data will only be valued if it is used. Ministries who invest in collecting routine data and monitoring reporting systems should leverage the data for decision making and promote their use across all levels of the health system. They should make their expectations of complete and high-quality data clear, and regularly review data in internal and public meetings to show how the data are being used. Translation of complex data into dashboards, data maps, and visualizations make this process compelling and amendable to a lay audience. How data can be used effectively is not a goal that is reached immediately, but a process explored in collaboration with stakeholders and partners.

\section{Recommendations for donors}

- Donors should request comprehensive monitoring and evaluation plans and indicator reference sheets from all implementing partners. It is essential that the implementing partners have a clear data collection and analysis system with indicator definitions, data source, and frequency of data collection clearly defined. When possible, standardized indicators should be promoted to increase comparability across project platforms and partners. Requiring transparency of program documentation and agreed upon open data policies is critical for program monitoring and evaluation.

- Donors should consider investing in project specific, household-based surveys that collect a greater number of SBC-relevant indicators than large national surveys such as DHS and PMA are able to. These datasets, when publicly available, become an important source of SBC-relevant data for other 
stakeholders as well. Such surveys are better aligned with monitoring program impact on intermediate and longer-term outcomes and, when aligned with program design and implementation plans, can be used for rigorously assessing the effectiveness and cost-effectiveness of programs.

- Donors should regularly convene and coordinate monitoring, evaluation, and learning partners nationally and regionally to facilitate the standardization of monitoring and evaluation plans, SBC indicators, and innovation in data collection methods, and ensure data-informed programmatic learnings are shared. These convenings could be facilitated and coordinated by a technical assistance partner with expertise in monitoring, evaluation, and learning.

- Donors should consider supporting governments to develop standardized systems to monitor data quality through targeted technical assistance.

- Donors should work with governments and implementing partners to ensure that SBC-related indicators are routinely monitored in global and regional partnerships supporting FP.

- Donors may consider further investing in knowledge management and research utilization projects to help stakeholders make the most of available data sources for program and policy decision making.

\section{Recommendations for research and measurement partners}

- FP stakeholders should participate in the development of a regional monitoring and evaluation framework that is inclusive of SBC programmatic investments and commit to incorporating applicable frameworks into their monitoring, evaluation, and learning plans.

- Large, recurring surveys such as the PMA surveys should incorporate measures for programmatic reach (particularly for large campaigns), as well as intermediate indicators beyond awareness of FP methods, such as knowledge, attitudes, self-efficacy, and social norms, as it may be more challenging for individual projects or programs to do so.

- Projects should also capture better data on men, FP/ $\mathrm{RH}$ related intermediate indicators, and how these are changing over time, as much of the current data collection efforts focus on women.

\section{Recommendations for implementers}

- Programs should commit to documentation transparency and open data to maximize the value of data collected for monitoring and evaluation. Timely provision of data for review, secondary analysis, and research utilization would maximize the value and impact of data.

- Programs should identify through a theory of change development process at the design stage and identify behavioral drivers to be addressed by programming to assess progress in achieving longer-term program outcomes and impact.

- There is a need for improved and more consistent measurement of program reach, particularly objective (exposure) rather than subjective (reported reach), to better understand service utilization data and to assess impact and the unit costs of reaching individuals for cost-effectiveness assessments.

- Where reached by interventions, projects should capture better data on key influencers to better understand how the enabling environment may facilitate or impede behavioral outcomes. Key influencers could include religious leaders, community leaders, male partners, extended family, depending on context.

- Routine monitoring data are important to establish the fidelity of program implementation. In addition to common output measures (such as number of community dialogue events held), we recommend that projects adopt indicators that measure quality of implementation (such as number of community dialogues that included at least three priority themes).

- There is a dearth of cost-related measures available to inform programs. Programs should leverage the availability of SBC costing guidelines to collect cost data and develop cost measures that can support advocacy, program prioritization, and agenda setting.

- While the goal of facilities is to improve outcomes for clients, there is a need to measure intermediate indicators such as changes to providers' knowledge, attitudes, and behaviors.

- $\mathrm{SBC}$ and service delivery partners would benefit from jointly reviewing supply- versus demand-side data. When reviewed jointly, partners may better map results, interpret findings, and identify programmatic needs. 


\section{Recommendations for the SBC indicator bank for family planning and service delivery}

- At the community level, there is a need to measure intermediate and outcome type indicators, for example, the percentage of community leaders who believe they are capable of advocating for FP use (self-efficacy).

- There is a need for additional SBC facility level measures. In particular, there should be indicators that capture provider exposure to SBC interventions, as well as more indicators that measure provider knowledge, attitudes, norms, and self-efficacy regarding interpersonal communication.

- Inclusion of SBC cost-related indicators is beneficial to all actors in budgeting and advocating for further investment. Such indicators may include: (1) cost per person reached by mass media interventions, (2) cost per person participating for interpersonal communication (IPC) and/or community engagement, (3) cost per couple years protection, (4) cost per pregnancy averted, and (5) cost per disability adjusted life year (DALY) averted.

- While policy indicators may be more difficult to capture quantitatively, we did note that there were few national/policy related indicators that captured reach and intermediate level indicators. It may be useful for the indicator bank to include indicators such as number of government leaders who feel they are able to speak out in favor of FP to better understand the policy context related to SBC.

\section{Limitations}

While we attempted to capture a complete list of FP indicators in the four WABA/Amplify-FP countries, we may not have identified all relevant stakeholders. Some stakeholders contacted did not respond or provide the requested information, particularly if they were not recipients of USAID funding. In addition, some indicators used by the government or projects may be duplicated by the institution responsible for data collection. However, information provided was not always complete and we did not have the opportunity to cross check each individual indicator. We also found that some of the program documents had missing data. In these instances, we attempted to resolve outstanding questions with our field-based consultants. We also recognize that indicators are subject to evolve over time as projects adapt to their context, new activities begin, and previous activities conclude. The indicators collected represent a snapshot of information collected at the time of the interview. Finally, we found some indicators did not fall neatly in the indicator type or socio-ecological definitions. In these instances, the team identified the closest definitions and then determined the appropriate code based on a discussion of the strengths and limitations of each classification. 


\section{Appendices}




\section{Appendix 1: List of contacts}

\begin{tabular}{|c|c|c|c|c|}
\hline NAME & COUNTRY & TITLE & ORGANIZATION & $\begin{array}{l}\text { PROVIDED } \\
\text { INFORMATION }\end{array}$ \\
\hline Dr Tanoh Gnou & Côte d'Ivoire & Directeur Coordonnateur & $\begin{array}{l}\text { Programme National de la Santé de la } \\
\text { Mère et de l'Enfant }\end{array}$ & \\
\hline Seka & Côte d'Ivoire & Directeur du Suivi Evaluation & $\begin{array}{l}\text { Programme National de la Santé de la } \\
\text { Mère et de l'Enfant }\end{array}$ & \\
\hline $\begin{array}{l}\text { Soro Donapoho } \\
\text { Amadou }\end{array}$ & Côte d'Ivoire & $\begin{array}{l}\text { Directeur Information } \\
\text { Stratégique }\end{array}$ & $\begin{array}{l}\text { Population Services International- } \\
\text { Côte d'Ivoire }\end{array}$ & $x$ \\
\hline Dr Ernest Konan Yao & Côte d'Ivoire & Directeur Pays & Pathfinder & \\
\hline Dr Kouadio Kouadio & Côte d'Ivoire & Amplify PF Country Manager & Pathfinder & $x$ \\
\hline Denise Adou & Côte d'Ivoire & Program Officer West Africa & Breakthrough ACTION & \\
\hline Hawa Talla & Côte d'Ivoire & $\begin{array}{l}\text { Directrice du Projet -The } \\
\text { Challenge Initiative (TCI) Af- } \\
\text { rique de l'Ouest Francophone }\end{array}$ & IntraHealth International, Senegal & \\
\hline $\begin{array}{l}\text { Monsieur Soro } \\
\text { Aboudou Nabiehoua }\end{array}$ & Côte d'Ivoire & $\begin{array}{l}\text { Regional advocacy and Part- } \\
\text { nership Manager }\end{array}$ & EngenderHealth $\mathrm{Cl}$ & $x$ \\
\hline Oura A Joachim & Côte d'Ivoire & Responsable Suivi Evaluation & $\begin{array}{l}\text { Alliance des Religieux pour la Santé In- } \\
\text { tégrale et la Promotion de la Personne } \\
\text { Humaine en Côte d'Ivoire (ARSIP) }\end{array}$ & $x$ \\
\hline Ouya Flore Rachelle & Côte d'Ivoire & $\begin{array}{l}\text { Assistante du Directeur } \\
\text { Exécutif }\end{array}$ & $\begin{array}{l}\text { Alliance des Religieux pour la Santé In- } \\
\text { tégrale et la Promotion de la Personne } \\
\text { Humaine en Côte d'Ivoire (ARSIP) }\end{array}$ & $x$ \\
\hline Dr Seydou Outara & Côte d'Ivoire & & $\begin{array}{l}\text { Programme National de Sante Scolaire } \\
\text { et Universitaire (PNSSU) }\end{array}$ & \\
\hline $\begin{array}{l}\text { Dr Yao-N'dry Akissi } \\
\text { Nathalie }\end{array}$ & Côte d'Ivoire & Director of Programs & $\begin{array}{l}\text { Association Ivoirienne Pour le } \\
\text { Bien-Etre Familial (AIBEF) }\end{array}$ & $x$ \\
\hline $\begin{array}{l}\text { Dr N'guessan - Koffi } \\
\text { Reine }\end{array}$ & Côte d'Ivoire & $\begin{array}{l}\text { Responsable Marketing et } \\
\text { Ventes }\end{array}$ & Agence Ivoirienne de Marketing Social & $x$ \\
\hline Goussou Lazare & Côte d'Ivoire & Directeur exécutif & Agence Ivoirienne de Marketing Social & $x$ \\
\hline Dr Male Momine & Côte d'Ivoire & $\begin{array}{l}\text { Direction de l'Informatique } \\
\text { et de l'Information Sani- } \\
\text { taire (DIIS)/Ministère de la } \\
\text { Santé et de l'Hygiène Publique } \\
\text { (MSHP) }\end{array}$ & & $x$ \\
\hline Yecoula Noe & Côte d'Ivoire & $\begin{array}{l}\text { Charge du Suivi Évaluation/ } \\
\text { Analyste de Données sani- } \\
\text { taires, Coordonnateur Adjoint }\end{array}$ & $\begin{array}{l}\text { CATCIS (Cellule d'appui technique au } \\
\text { Système sanitaire) }\end{array}$ & $x$ \\
\hline Dr Talibo Almouner & Côte d'Ivoire & Program Specialist FP/RHCS & UNFPA CO Côte d'Ivoire & \\
\hline Dr N'da Constant & Côte d'Ivoire & & UNFPA & \\
\hline Kambire Serges & Côte d'Ivoire & $\begin{array}{l}\text { Les jeunes ambassadeurs de } \\
\text { PF }\end{array}$ & & \\
\hline Coulibaly Sibir & Côte d'Ivoire & Directeur Exécutif & ONG Fondation DJEDJE & \\
\hline $\begin{array}{l}\text { Dr Agossou Abram } \\
\text { Amétépé }\end{array}$ & Togo & $\begin{array}{l}\text { Directeur de DSME, Ministère } \\
\text { de la Santé, Togo }\end{array}$ & $\begin{array}{l}\text { Direction de Santé de la Mère et de } \\
\text { l'Enfant (DSME) }\end{array}$ & $x$ \\
\hline \multirow[t]{2}{*}{ Napo Dare } & \multirow[t]{2}{*}{ Togo } & \multirow{2}{*}{$\begin{array}{l}\text { Chargé du Suivi Evaluation } \\
\text { DSMI-PF, Coordonnateur } \\
\text { Track20 }\end{array}$} & DSMI-PF & \multirow[t]{2}{*}{$x$} \\
\hline & & & Track20 & \\
\hline Thomas Deglo & Togo & $\begin{array}{l}\text { Représentant JHPIEGO au } \\
\text { Togo }\end{array}$ & JHPIEGO & $x$ \\
\hline $\begin{array}{l}\text { Dr Emmanuel Yawo } \\
\text { Agbigbi }\end{array}$ & Togo & $\begin{array}{l}\text { Maternal Health, Reproduc- } \\
\text { tive Health and Commodities } \\
\text { Security Coordinator }\end{array}$ & UNFPA/Togo & $x$ \\
\hline
\end{tabular}




\begin{tabular}{|c|c|c|c|c|}
\hline Alina Berendsen & Togo & Conseiller Technique & $\begin{array}{l}\text { Projet pour le Renforcement du Sys- } \\
\text { tème Sanitaire-Sante Reproduction et } \\
\text { Droits Sexuels (ProSanté) }\end{array}$ & $x$ \\
\hline Hilaire Tokplo & Togo & Country Program Officer & Breakthrough ACTION & $x$ \\
\hline Abalo Charle Limazie & Togo & & Health Policy Plus, Palladium Group & $x$ \\
\hline Macoumba Thiam & Togo & M\&E and Learning Advisor & USAID AmplifyPF Project & $x$ \\
\hline $\begin{array}{l}\text { Dr Komlan Sélom } \\
\text { Noussoukpoe }\end{array}$ & Togo & Directeur de programme & $\begin{array}{l}\text { Association Togolaise Pour le Bien-Etre } \\
\text { Familial (ATBEF) }\end{array}$ & $x$ \\
\hline Koffi Edem Dzotsi & Togo & M\&E Unit Director & $\begin{array}{l}\text { Association Togolaise Pour le Bien-Etre } \\
\text { Familial (ATBEF) ; Ouagadougou Part- } \\
\text { nership Focal Point for Civil Society }\end{array}$ & \\
\hline $\begin{array}{l}\text { Yawo Serge Prince-Ag- } \\
\text { bodan }\end{array}$ & Togo & $\begin{array}{l}\text { Coordonnateur Réseau des Or- } \\
\text { ganisations de la Société Civile } \\
\text { en Santé de la Reproduction } \\
\text { et Planification Familiale, Coor- } \\
\text { dinateur pays }\end{array}$ & Intrahealth & $x$ \\
\hline Kandasi Griffiths & Togo & $\begin{array}{l}\text { Spécialiste de Renforcement } \\
\text { des Systèmes de Santé }\end{array}$ & Santé Intégrée & $x$ \\
\hline Andrew Lopez & Togo & Directeur des partenariats & Santé Intégrée & $x$ \\
\hline Jules Broko & Togo & Chargé du Suivi Evaluation & ONG ADESCO & $x$ \\
\hline Afo Medjessiribi & Togo & $\begin{array}{l}\text { Chargé du Suivi Evaluation, } \\
\text { Coordinateur par intérim } \\
\text { Plateforme }\end{array}$ & OSC/VIH/PF & $x$ \\
\hline Komlavi Noulagbessi & Togo & $\begin{array}{l}\text { ONG Jourdain Vie et Santé } \\
\text { (JVS) }\end{array}$ & JVS & \\
\hline Mimboab Yangnenam & Togo & Coordinateur de l'ONG & 3ASC & \\
\hline Dr Kelem Atany & Togo & & Plan International Togo & \\
\hline Mme Essohouna B & Togo & & SOS Village d’Enfants Togo Lomé & \\
\hline $\begin{array}{l}\text { Dr Josette Vignon } \\
\text { Makong }\end{array}$ & Niger & Inspire project (Pilot Project) & $\mathrm{HKI}$ & \\
\hline Edwige Hounon & Niger & & MSI & \\
\hline Rose Barnes Covenant & Niger & RISE I PF & PSI & $x$ \\
\hline $\begin{array}{l}\text { Foureratou Yahaya } \\
\text { Touraoua }\end{array}$ & Niger & & Animas Sutura & \\
\hline Dr Marcel Lucien Omar & Niger & $\begin{array}{l}\text { Mother / Child Health Director- } \\
\text { ate (DSME) }\end{array}$ & Ministry of Public Health & $x$ \\
\hline $\begin{array}{l}\text { Dr Abdou-Ouma } \\
\text { Kaltouma }\end{array}$ & Niger & Family Planning Division & & $x$ \\
\hline Soumana Abdourahim & Niger & $\begin{array}{l}\text { DSME Monitoring and Evalua- } \\
\text { tion Division }\end{array}$ & & $x$ \\
\hline Mr. Mahamidou Illo & Niger & $\begin{array}{l}\text { Directorate of Documentation } \\
\text { Information, Archives and } \\
\text { Public Relations (DIDARP) }\end{array}$ & & \\
\hline Dr Mounkaila Aïda & Niger & Direction des statistiques & & $x$ \\
\hline DrAtté & Niger & Direction de la nutrition & & $x$ \\
\hline Badara Sèye & Niger & Breakthrough ACTION & Save the Children & $x$ \\
\hline Dr Sani Aliou & Niger & Country Director & Pathfinder & \\
\hline Dr Asma Yaro Gali & Niger & & Amplify-PF Project & \\
\hline Idrissa Adamou & Niger & & IMPACT Project & \\
\hline Dr Mohamed Dicko & Niger & RHCS Technical Specialist & UNFPA, Niger & \\
\hline
\end{tabular}




\begin{tabular}{|c|c|c|c|c|}
\hline $\begin{array}{l}\text { Abdel Razak Boureima } \\
\text { Yeya }\end{array}$ & Niger & Focal Point HP+ /DSME & Health Policy Project (HP+) & \\
\hline Zakou Harouna & Niger & Focal Point/DSME & Track 20 & \\
\hline Mahamadou Balarabé & Niger & Projet TCl & Intrahealth & \\
\hline $\begin{array}{l}\text { Dr Karim Maiga Abdou- } \\
\text { laye }\end{array}$ & Niger & General Coordinator & Association Nigérienne pour (ANBEF) & $x$ \\
\hline M. Ali Adamou & Niger & Monitoring \& Evaluation & Association Nigérienne pour (ANBEF) & \\
\hline $\begin{array}{l}\text { Tabiojong Mbeng } \\
\text { Benedict }\end{array}$ & Niger & Head of Nutrition unit & PAM & $x$ \\
\hline Tijani Bintou & Niger & Nutrition & UNICEF & \\
\hline Hélène & Niger & Nutrition & $\mathrm{ECHO}$ & \\
\hline Amadou Alzouma & Niger & & OMS & \\
\hline Adamou Moumouni & Niger & & & \\
\hline Idrissa Maiga & Niger & $\begin{array}{l}\text { Projet Genre Population et } \\
\text { Développement au Niger } \\
\text { (GPDN) }\end{array}$ & Agence Française de Développement & $x$ \\
\hline Ali Boubacar Doungou & Niger & $\begin{array}{l}\text { Sahel Women's Empowerment } \\
\text { and Demographic Dividend } \\
\text { Project (SWEDD) }\end{array}$ & Banque Mondiale & \\
\hline Manzo & Niger & & ANIMAS SUTURA & $x$ \\
\hline Kasella Idrissa & Niger & & Fonds Mondial & \\
\hline Oumarou Maigari & Niger & Coordonnatrice & ENABEL & $x$ \\
\hline Dr Fati Zarmakoye & Niger & & LAHIYA MATASSA & $x$ \\
\hline Issa Sabo & Niger & & & \\
\hline $\begin{array}{l}\text { Dr Djermakoye Hadiza } \\
\text { Jackou }\end{array}$ & Niger & Coordinatrice Nationale & $\begin{array}{l}\text { Programme National de Lutte contre } \\
\text { le Paludisme (PNLP - NIGER) }\end{array}$ & \\
\hline Mourtala Assao & Niger & Coordinateur National & $\begin{array}{l}\text { Programme National de Lutte contre } \\
\text { la Tuberculose }\end{array}$ & \\
\hline Dr Yara Mintou & Niger & & $\begin{array}{l}\text { Programme national de lutte contre le } \\
\text { SIDA et les hépatites }\end{array}$ & \\
\hline Benjamin Babunga & Niger & HAMZARI & CARE & $x$ \\
\hline Sani Allassane & Niger & Terres Eau Vie & Winrock & $x$ \\
\hline $\begin{array}{l}\text { Abdourahamane } \\
\text { Abdou }\end{array}$ & Niger & Wadara & Save the Children & $x$ \\
\hline Eric & Niger & GIRMA & CRS & $x$ \\
\hline Zakari Congo & Burkina Faso & $\begin{array}{l}\text { Monitoring and Evaluation } \\
\text { Director \& Local Compliance } \\
\text { Officer }\end{array}$ & Pathfinder International & $x$ \\
\hline Gisèle Kabore & Burkina Faso & AFP Project Director & Amplify - FP & $x$ \\
\hline $\begin{array}{l}\text { Jeanne D’arc Paré/ } \\
\text { Somé }\end{array}$ & Burkina Faso & $\begin{array}{l}\text { Capacity Strengthening and } \\
\text { Community Engagement } \\
\text { Advisor }\end{array}$ & Breakthrough ACTION & $x$ \\
\hline $\begin{array}{l}\text { Cheick Oumar Oue- } \\
\text { draogo }\end{array}$ & Burkina Faso & $\begin{array}{l}\text { Project Director -Post Partum } \\
\text { Family Planning (PPFP) }\end{array}$ & Jhpiego & $x$ \\
\hline Mathurin Dodo & Burkina Faso & $\begin{array}{l}\text { Director of Monitoring, Evalua- } \\
\text { tion and RESEARCH (D-MER) }\end{array}$ & Jhpiego & $x$ \\
\hline Oscar Koalaga & Burkina Faso & $\begin{array}{l}\text { Previous Country Project } \\
\text { Director (AgirPF) }\end{array}$ & EngenderHealth & $x$ \\
\hline Maka Barry & Burkina Faso & $\begin{array}{l}\text { Regional Administrative \& } \\
\text { Financial Officer }\end{array}$ & EngenderHealth & $x$ \\
\hline
\end{tabular}




\begin{tabular}{|c|c|c|c|c|}
\hline Richard Boustred & Burkina Faso & $\begin{array}{l}\text { West \& Central Africa - Région- } \\
\text { al Director }\end{array}$ & DKT International & $x$ \\
\hline Seydou Boudo & Burkina Faso & M\&E Officer MS Burkina Faso & Marie Stopes Burkina Faso & $x$ \\
\hline Aminata Rabo & Burkina Faso & $\begin{array}{l}\text { Country Team Leader/PP } \\
\text { Global }\end{array}$ & $\begin{array}{l}\text { Planned Parenthood Global (PP } \\
\text { Global) }\end{array}$ & $x$ \\
\hline Dr. Philippe Sanou & Burkina Faso & SRH Project Director & IntraHealth International & $x$ \\
\hline Dr. Brahima Bassane & Burkina Faso & $\begin{array}{l}\text { HP+ West Africa's regional } \\
\text { Deputy Director }\end{array}$ & Health Policy Plus (HP +) & \\
\hline Dr. Narcisse Salembere & Burkina Faso & $\begin{array}{l}\text { SRH Project Director - Closing } \\
\text { the gap }\end{array}$ & $\begin{array}{l}\text { Société des gynécologues et obstétric- } \\
\text { iens du Burkina (SOGOB) }\end{array}$ & $x$ \\
\hline Dr. Ida Kagone & Burkina Faso & Technical Secretary & $\begin{array}{l}\text { Secrétariat Technique Chargé de } \\
\text { l'Accélération de la Transition Démo- } \\
\text { graphique (Ministère de la Santé) }\end{array}$ & $x$ \\
\hline Dr. Pierre Yameogo & Burkina Faso & Technical Secretary & $\begin{array}{l}\text { Secrétariat Technique Chargé de } \\
\text { la Couverture Santé Universelle } \\
\text { (Ministère de la Santé) }\end{array}$ & $x$ \\
\hline Nadine Tamboura & Burkina Faso & Technical Secretary & $\begin{array}{l}\text { Secrétariat Technique Chargé de la } \\
\text { Coopération au Développement Sani- } \\
\text { taire(Ministère de la Santé) }\end{array}$ & $x$ \\
\hline André Yollan Ky & Burkina Faso & Director & $\begin{array}{l}\text { Directeur de la Santé de la Famille } \\
\text { (Ministère de la Santé) }\end{array}$ & \\
\hline Eliane Sow & Burkina Faso & $\begin{array}{l}\text { SBC officer / Directorate for } \\
\text { the Promotion of Health } \\
\text { Education }\end{array}$ & $\begin{array}{l}\text { Direction de la Promotion de l’Educa- } \\
\text { tion Sanitaire (Ministère de la Santé) }\end{array}$ & $x$ \\
\hline Saturnin Zoetyande & Burkina Faso & Statistician \& M\&E & Options (Projet WISH) & $x$ \\
\hline Simplice Toe & Burkina Faso & $\begin{array}{l}\text { Team Leader-SRH Technical } \\
\text { Advocacy group }\end{array}$ & $\begin{array}{l}\text { Groupe Technique Santé de la Repro- } \\
\text { duction (GT/SR) }\end{array}$ & $x$ \\
\hline Angèle Sourabie & Burkina Faso & Program Director & $\begin{array}{l}\text { Association Burkinabé pour le Bien } \\
\text { Être Familial (ABBEF/IPPF) }\end{array}$ & $x$ \\
\hline Mariam Nonguierma & Burkina Faso & President of ABSFME & $\begin{array}{l}\text { Association des Sagefemmes et des } \\
\text { Maïeuticiens d'Etat (ABSFME) }\end{array}$ & $x$ \\
\hline Mireille Belem & Burkina Faso & Research Officer & $\begin{array}{l}\text { Développement Media International } \\
\text { (DMI) }\end{array}$ & $x$ \\
\hline Francois Laureys & Burkina Faso & VIAMO Country Manager & VIAMO & \\
\hline Guy Martial Bai & Burkina Faso & $\begin{array}{l}\text { Statistician-Research Assistant } \\
\text { - Higher Institute of Population } \\
\text { Sciences }\end{array}$ & $\begin{array}{l}\text { Institut Supérieur des Sciences de la } \\
\text { Population (ISSP - PMA Burkina) }\end{array}$ & $x$ \\
\hline $\begin{array}{l}\text { Dr. Emmanuelle } \\
\text { Sempore }\end{array}$ & Burkina Faso & Chargé de Mission & $\begin{array}{l}\text { Institut National de Santé Publique } \\
\text { (INSP) }\end{array}$ & $x$ \\
\hline Dr. Danielle Belemsaga & Burkina Faso & Economist \& Research Officer & $\begin{array}{l}\text { Institut de Recherche en Science de la } \\
\text { Santé (IRSS) }\end{array}$ & $x$ \\
\hline
\end{tabular}




\section{Appendix 2: Questionnaire for stakeholders}

Country:

Structure/organization:

Type of respondent (Project managers and/or monitoring \& evaluation managers):

Project title:

Donor:

Questions to ask:

1. What does the health care project (s) do?

2. When did the project start and when / should it end?

3. What are the different areas of intervention of the project?

a. Advocacy (strategic use of information to influence policies, practices, attitudes and beliefs that affect people's lives / behavior)

b. Service offer (all services and care made available to the population by professionals and health care systems to meet the needs of the population).

c. Demand creation - social and behavioral change (strategy that aims to generate interest and desire to buy / use a given product or service)

d. Product security (activity that ensures access to quality health products)

e. Coordination (harmonization of various activities for the sake of efficiency)

f. Research (all actions taken to produce and develop scientific knowledge)

g. Monitoring and evaluation (activities that assess the progress made towards achieving the goal and objectives of an intervention, as well as the factors influencing this progress).

4. For each of the above areas of intervention, what specific approaches / strategies do you use?

5. In which zones (regions, departments, districts, etc.) do you operate?

6. Are you implementing all the strategies mentioned in point 3 equally in all these regions, zones, districts? If not, what do you do specifically for each zone?

7. Who is your / who are your implementing partners for the project?

8. What indicators do you use to monitor your activities?

a. What process indicators do you use to help you know you are on the right track?

b. What outcome indicators do you use to report results?

c. Who do you communicate these indicators to?

d. How do you define these indicators (ask for a copy of the indicator reference sheets)?

e. How do you collect the data that allow you to report on these indicators (what are the sources of data for these indicators)?

f. Do you face any problems or challenges when collecting and reporting on these quality indicators? If so, what are the main challenges?

9. Has your project been / will it be evaluated? If yes, what type of evaluation? At what moment ?

10. Are there other actors / projects that you consider relevant for us to meet within the framework of this mapping? 


\section{Appendix 3: Indicator matrix of FP investments across the four WABA/ Amplify-FP countries}

See separate excel file available at: http://breakthroughactionandresearch.org/wp-content/uploads/2020/04/WABAFP-IndicatorMap-Appendix3-Matrix.xlsx

\section{Appendix 4: Summary presentation of FP stakeholder investments across the four WABA/Amplify-FP countries}

See separate powerpoint presentation available at: http://breakthroughactionandresearch.org/wp-content/ uploads/2020/04/WABA-FP-IndicatorMap-Appendix4-Summary.pptx

\section{Appendix 5: References}

1. Ahmed, S, Q. Li, L. Liu, and A. O. Tsui. 2012. "Maternal deaths averted by contraceptive use: an analysis of 172 countries," The Lancet 380(9837): 111-25. doi: 10.1016/S0140-6736(12)60478-4

2. Breakthrough ACTION. 2019. Synthèse des champs d'influence et stratégies réssortantes-région PO [Internet; cited 2020 Mar 23]. Available from: https://breakthroughactionandresearch.org/wp-content/uploads/2019/09/OP-Influence-Strategy-FR.pdf

3. Weinberger, M., E. Sonneveldt, and J. Stover. 2017. "The maximum contraceptive prevalence 'demand curve': guiding discussions on programmatic investments," Gates Open Research 1: 15. doi: 10.12688/gatesopenres.12780.1

4. Rosen, James E. et al. 2019. The Business Case for Investing in Social and Behavior Change for Family Planning. Breakthrough RESEARCH. Washington DC: Population Council. https://breakthroughactionandresearch.org/wp-content/uploads/2020/01/20191211_BR_FP_SBC_Gdlns_Final.pdf

5. Kincaid, D. L. 2000. "Social networks, ideation, and contraceptive behavior in Bangladesh: a longitudinal analysis," Social Science \& Medicine 50(2): 215-31.

6. Frankel, N., and A. Gage. 2007. "M\&E fundamental a self-guided mini-course [Internet]." MEASURE Evaluation. Available from: https://www.measureevaluation.org/resources/publications/ms-07-20-en

7. McLeroy, K. R., D. Bibeau, A. Steckler, and K. Glanz. 1988. "An ecological perspective on health promotion programs," Health Education \& Behavior 15(4):351-377. doi: 10.1177/109019818801500401

8. FHI360. 2020. "Communication for Health: Final Project Report." Accra, Ghana: FHI360. 


\section{Population Council}

4301 Connecticut Ave., NW | Suite 280

Washington, DC 20008

+12022379400

breakthroughactionandresearch.org 